\title{
Performance Analysis of Fuzzy AHP in The Rankings
}

\author{
Teuku Afriliansyah ${ }^{1,2}$, Erna Budhiarti Nababan ${ }^{2}$, and Zakarias Situmorang ${ }^{2}$ \\ \{teuku_afriliansyah@students.usu.ac.id\} \\ ${ }^{1}$ STKIP Bumi Persada Lhokseumawe, Lhokseumawe, Indonesia \\ ${ }^{2}$ Department of Computer Science, Universitas Sumatera Utara, Medan, Indonesia
}

\begin{abstract}
Analytic Hierarchy Process can solve complex multicriteria problemsinto a hierarchy. hierarchy is defined as a representation of a complex problem in a multi-level structure where the first level is the goal, followed by the factor level, criteria, sub criteria, and so on down to the last level of the alternative (Saaty, 2008). Selection of employees achievement aims to provide encouragement, dedication, loyalty, professionalism and high motivation to employee performance. In this research, Hierarchical Process Analysis Method is used to search the ranking weight, then used Fuzzy AHP method as a comparison, then tested to get employee performance accuration. Fuzzy AHP is a combination of Hierarchical Process Analysis method with fuzzy concept approach. Fuzzy AHP covers the existing weaknesses in Hierarchical Process Analysis, problems with criteria that have more subjective properties. Final conclusions Fuzzy AHP still get more value than using Hierarchy Analysis Process. The percentage of weight gain is $21 \%, 8 \%, 9 \%, 11 \%, 14 \%, 7 \%, 17 \%, 15 \%, 10 \%$, and $14 \%$ respectively. The difference of the results obtained is due to the weight difference of each criterion value that exists. Furthermore, the calculation of accuration, test results show Fuzzy AHP method gets accuracy of $72 \%$.
\end{abstract}

Keywords: Hierarchy Analysis Process, Fuzzy AHP, Accuration

\section{Introduction}

Analytic Hierarchy Process (AHP) is one of the methods that can be used in decisionmaking system by considering the factors of perception, preference, experience and intuition. AHP can be to combines personal judgment and values into a logical way. AHP can solve complex multicriteria problems into a hierarchy. A complex problem can be interpreted as the criteria of a multicriti- ty, the uncertainty of the problem structure, the uncertainty of opinion from the decision maker, the decision-maker of more than one person, and the inaccuracy of available data.According to [1], Hierarchy is defined as a representation of a complex problem in a multi-level structure where the first level is the goal, followed by the factor level, criteria, sub criteria, and so on down to the last level of the alternative. With a hierarchy, a complex problem can be broken down into groups that are then organized into a hierarchical form so that the problem will seem more structured and systematic.

According to [2], "Fuzzy AHP to determine the relative weights of evaluation criteria and Fuzzy TOPSIS to rank the alternatives", Fuzzy AHP to determine the relative weighting of evaluation criteria and Fuzzy Topsis to determine the accuracy of the data, whereby the 
decision consists of three levels: at the highest level, the purpose of the problem lies on the second level, that is, the Criteria listed, and at the third level, the listed sub criteria; The Topsis method yields Sc1 - Sc4 (0.3333) while for Sc5 (0.2).

While the first Fuzzy Analytic Hierarchy Process requires a pairwise Comparison of criteria and sub criteria to determine its weight. Last level belongsalternative. So the criterion 1 is $(0.3333333)$ and sub criterion $1(0,425)$, sub criterion $2(0,575)$ and criterion 2 produce $(0,666666)$ from sub criterion $11(0,644835)$, sub criterion $12(0,244575)$ and sub criterion 3 (0.11059). This consistent comparison matrix indicates that the previous Sub criterion has fewer values than the normalized priority weighting between the two generates the main criteria and the five sub criteria and their ranking. The results showed that the weight generated using fuzzy topsis alternatives showed inaccurate data, so the solution was selected Fuzzy AHP. According to [2], "Comparison of Fuzzy AHP and Fuzzy TOPSIS Methods for Math Teachers Selection" The incorporation of Fuzzy AHP and Fuzzy Topsis Methods for mathematics teacher selection, where the results show the AHP fuzzy method for teacher selection problems mathematics proposed in a group decision based on AHP fuzzy.

First, the decision maker prepares the questionnaire form and then with other interest sharing performs the pairing comparison. Decision makers use linguistic variables, to evaluate alternative rankings with respect to each criterion and they turn them into triangular fuzzy numbers resulting in three (3) best teachers with the weight of T1 (0.31182), T2 (0.39977) and $\mathrm{T} 3$ (0.30968). The T2 alternative that has the highest priority weight is chosen as the best mathematics teacher choice. The alternate ranking sequence with the fuzzy AHP method is $\mathrm{T} 2>\mathrm{T} 1>\mathrm{T} 3$.

The best ranking weights are obtained using several criteria. Factors that support performance include Worker-made Needs, Ability, Complexity, Commitment, Feedback, Attitudes to each activity, Perseverance, Obedience and Have clear standards. The closer to the value of the given criterion the better the result.

According to [3], "Decision Support Systems for Selection of Performing Employees Based on Performance using the Analityc Hierarcy Process Method" produces 10 outstanding employees based on their performance. The results of the total weight calculation of each alternative using AHP and Fuzzy AHP, and from CR (Consistency Ratio), both results show consistent results by using AHP Alternative A Weight (0.1596), B (0.6349) and C (0.2055), while using the Azz fuzzy AHP alternative employee A (0.4869), B (0.3561) and C (0.1570). So based on AHP calculation, the choice of candidates from the highest score to terenda are candidates B, C, and A. While the calculation of Fuzzy AHP, obtained the sequence A, B and C.Based on the research descriptions, the authors looked at some of the differences in increasing the accuracy as well as the specified weights. According to (Ridyanningtias 2013), the measure of employee performance is one important factor. If you can not measure it, it causes difficulties in managing management. The effect of performance measurement has a major impact on existing human resource activities. Several performance appraisal methods, consisting of Graphic Rating Scale Method, Method of Behavioral Valuation Scale, Management Method Based on Goal (Gibson, 1994). 
For that the authors conclude that differences in processing and development procedures studied by previous researchers can be appointed as a reference in analyzing this research topic, which to obtain good accuracy data using weighting criteria that will be analyzed using Fuzzy AHP in improving the accuracy of AHP techniques can applied to get a better accuracy, therefore the authors make a study with the title "Performance Analysis Of Fuzzy Analytic Hierarchy Process In The Rangkings.".

\section{Methods}

This research, several important points of AHP and fuzzy AHP are briefly described, among others, the data used derived from questionnaires and interviews. Of the 150 questionnaires distributed, only 100 questionnaires were returned. Furthermore, for interviews that are used as resource persons namely the chairman of Prodi, lppm chairman and chairman of the foundation of earth finance persada. Research conducted sincea years ago.

\subsection{AHP}

Analitic Hierarchy Process (AHP) defined as a representation of a complex problem in a multilevel structure where the first level is the goal, followed by the factor level, criteria, sub criteria, and so on down to the last level of the alternative [4]. AHP requires the selection of alternative values in pairwise comparisons because it has the nature of uncertainty and should be reconsidered in many pairwise comparison assessments ( $\mathrm{Yu}, 2002)$.

The problem solving process using AHP method is described as follows:

1. For each value in the first column multiplication must be done with relative priority columns on the first element, then the value in the second column must be multiplied by the relative priority column of the second element. Do so until the first column and relative priority columns on the th menu.

2. Add each row.

3. Furthermore the result of the sum of rows divided by relative priority elements.

4. Sum it up with the number of elements used.

5. Next, calculate the consistency index (CI) using the formula $\mathbf{C I}=(\boldsymbol{\lambda} \mathbf{m a x}-\mathbf{n}) /(\mathbf{n}-\mathbf{1})$

6. After the CI value is obtained, divide by Consistency Ratio (CR) using the formula: $\mathbf{C R}=\mathbf{C I} / \mathbf{R I}$. 


\subsection{Fuzzy AHP}

Decision-making models need to tolerate ambiguity because uncertainty is a common feature in many decision-making issues ( $\mathrm{Yu}, 2002)$. Because decision makers often provide uncertain answers rather than exact values, the transformation of a qualitative preference to an approximate point may not make sense.

This decision-making is obtained by several stages. By using the Structure Hierarchy then obtained goals / goals to be achieved, the criteria used and alternatives. Structure The hierarchy used can be seen in figure 1 .

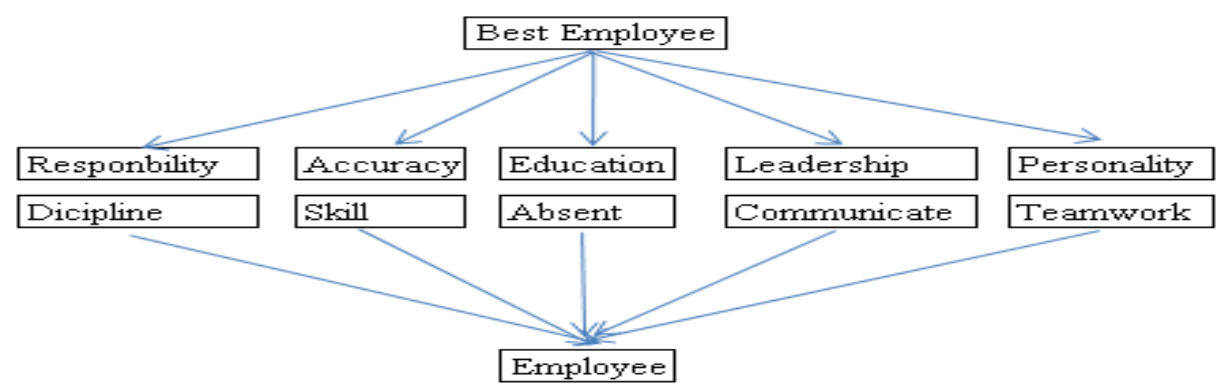

Figure 1 Hierarchy Structure

Fuzzy AHP procedure follows the rules steps by:

1.Creating a Hierarchy Structure

2. Create a Triangular Fuzzy Number (TFN);

3. Determining the value of fuzzy systesis $(\mathrm{Si})$ :

4. Determining the value of vector $(\mathrm{V})$ and Defuzzify Ordinate value (d ');

5. Normalization of fuzzy vector weight values (W) Normalized vector weight values;

6. Conduct a comparison of data accuracy on AHP and Fuzzy AHP;

\section{Result}

This research used survey method with field data collecting technique 150 respondents and interviewed to 3 resource persons namely chairman of Prodi, Chairman of LPPM and Chairman of Bina Bumi Persada Foundation. Of the 150 questionnaires distributed, only 100 questionnaires were returned. Research conducted since January until December 2016. The stages of this study started from data collection, data processing, problem formulation, testing stages and data analysis described in the form of diagrams in Figure 2. 


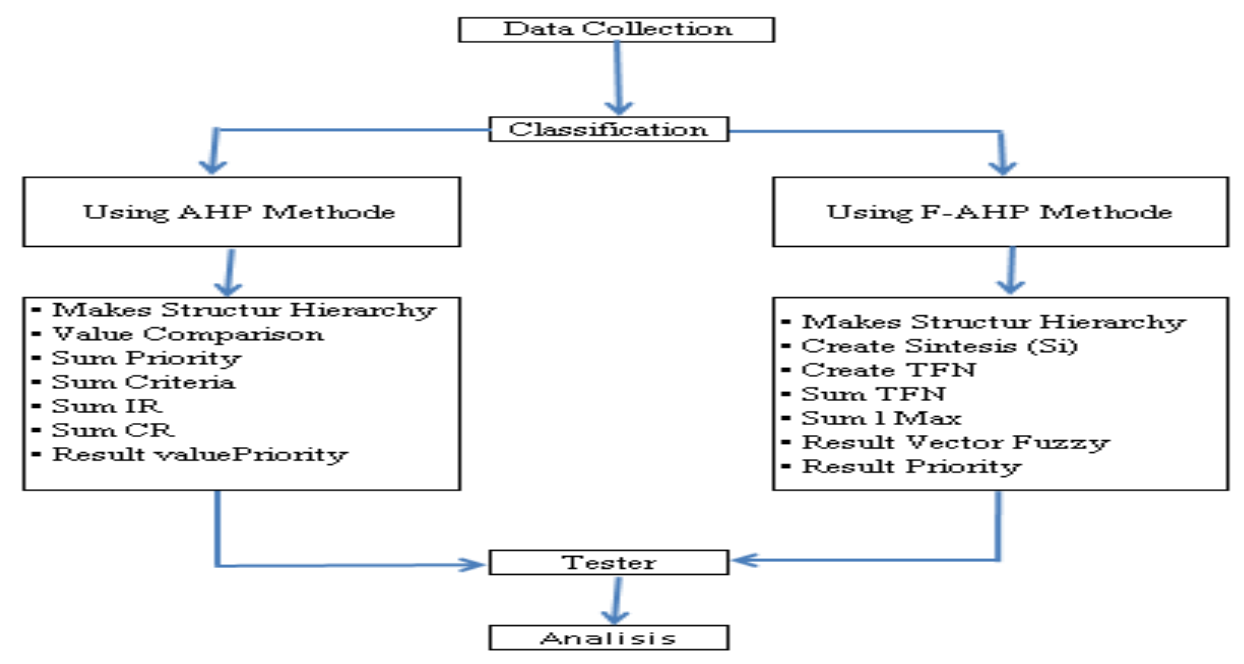

Figure 2. Flow Diagram

Data from respondent survey questionnaires using AHP and Fuzzy AHP methods are as follows:

Using AHP methods

The first stage is the comparison of criteria and alternatives, and the calculation of the weight of the value needs to be done. Thus, evaluation criteria according to the main objectives and evaluation of alternative criteria should be realized. The next step, after all these evaluation procedures, the alternative weights can be calculated. In the second step, this weight is used for AHP calculations for final evaluation. Comparison matrix for criteria. Table 1.

Table1. Value Matriks Comparison.

\begin{tabular}{|c|c|c|c|c|c|c|c|}
\hline $\mathrm{X} 1$ & $\mathrm{X} 2$ & $\mathrm{X} 3$ & $\mathrm{X} 4$ & $\mathrm{X} 5$ & $\mathrm{X} 6$ & $\mathrm{X} 7$ & $\mathrm{X} 8$ \\
\hline 1 & 3 & 5 & 5 & 3 & 5 & 1 & 3 \\
\hline 0,33 & 1 & 5 & 7 & 5 & 3 & 3 & 1 \\
\hline 0,14 & 0,20 & 1 & 3 & 1 & 1 & 2 & 3 \\
\hline 0,11 & 0,14 & 0,33 & 1 & 2 & 1 & 0,3 & 1 \\
\hline 0,14 & 0,20 & 1,00 & 0,50 & 1 & 3 & 2 & 0,33 \\
\hline 0,20 & 0,33 & 1,00 & 1,00 & 0,33 & 1 & 0,2 & 0,75 \\
\hline 1,00 & 0,33 & 7,00 & 0,33 & 0,50 & 5,00 & 0,2 & 0,5 \\
\hline 0,33 & 1,00 & 21,00 & 27,00 & 0,50 & 15,00 & 3,00 & 1 \\
\hline 3,73 & 6,21 & 12,16 & 21,53 & 20,36 & 20,33 & 9,73 & 10,58 \\
\hline
\end{tabular}

Calculate value matrix is normalized as follows:

$\mathrm{X} 1=\quad(1 / 7,2),(0,3 / 7,2),(0,3 / 7,2),(2 / 7,2),(2 / 7,2),(0,2 / 7,2),(1 / 7,2)$

$\mathrm{X} 2=\quad(3 / 12,2),(1 / 12,2),(0,5 / 12,2),(0,3 / 12,2),(3 / 12,2),(0,33 / 12,2),(3 / 12,2)$

$\mathrm{X} 3=(3 / 13),(2 / 13),(1 / 13),(0,5 / 13),(0,5 / 13),(3 / 13),(2 / 13),(1 / 13)$ 
Alternative weights are calculated with AHP then the weight of this value can be used on FAHP. Thus, the AHP methodology should begin in the first step. Thus, the initialized normalized decision matrix can be used as a reference which can be seen in table 2 .

Table2. Normalized Matriks values.

\begin{tabular}{|c|c|c|c|c|c|c|c|}
\hline $\mathrm{X} 1$ & $\mathrm{X} 2$ & $\mathrm{X} 3$ & $\mathrm{X} 4$ & $\mathrm{X} 5$ & $\mathrm{X} 6$ & $\mathrm{X} 7$ & $\mathrm{X} 8$ \\
\hline 0,268 & 0,483 & 0,247 & 0,232 & 0,147 & 0,246 & 0,103 & 0,284 \\
\hline 0,089 & 0,161 & 0,411 & 0,325 & 0,246 & 0,148 & 0,308 & 0,095 \\
\hline 0,089 & 0,032 & 0,082 & 0,139 & 0,049 & 0,049 & 0,206 & 0,284 \\
\hline 0,054 & 0,023 & 0,027 & 0,046 & 0,098 & 0,049 & 0,034 & 0,095 \\
\hline 0,089 & 0,032 & 0,082 & 0,023 & 0,049 & 0,148 & 0,021 & 0,031 \\
\hline 0,054 & 0,054 & 0,082 & 0,046 & 0,016 & 0,049 & 0,021 & 0,071 \\
\hline 0,268 & 0,054 & 0,041 & 0,141 & 0,246 & 0,246 & 0,103 & 0,047 \\
\hline 0,089 & 0,161 & 0,027 & 0,046 & 0,149 & 0,066 & 0,206 & 0,095 \\
\hline 1,000 & 1,000 & 1,000 & 1,000 & 1,000 & 1,000 & 1,000 & 1,000 \\
\hline
\end{tabular}

After obtaining the value of the matrix, then determine the priority of choice (Synthesis of Priority) is done by calculating the Priority Evaluation Value which includes:

a. Calculates a factor value in a table column.

b. Calculating the value of factors in the table used scales 1 through 9 that refer to table 3 .

Rating Scale.

c. Divide each factor value in a column by the total value of the calculation per column.

d. Calculates the average value of a row by calculating the value of a factor per row.

Table 3. Results Amount and Priority

\begin{tabular}{|c|c|c|}
\hline Goal & Amount & Prioritaty \\
\hline X1 & 2,009 & 0,270 \\
\hline X2 & 1,782 & 0,157 \\
\hline X3 & 0,930 & 0,033 \\
\hline X4 & 0,426 & 0,057 \\
\hline X5 & 0,475 & 0,084 \\
\hline X6 & 0,393 & 0,029 \\
\hline X7 & 1,145 & 0,103 \\
\hline X8 & 0,839 & 0,266 \\
\hline
\end{tabular}

The result of the average value of the line above is known that the priority of responsibility has the highest value, that is 0.270 but can not be set as the criteria value chosen before determining the consistency ratio level. 
Next calculate the Consistency Ratio (CR), ie evaluate the consistency level of the assessment given in the pairwise comparison stage. Determine CR using the Weighted Sum Vector formula, ie by multiplying the result of the mean value of the row by each factor value in the Pairwise comparison table. To determine the value of consistency vector by dividing the value of weighted sum vector with the average value of result of Consistency Vector:

Table 4. Consistency Vector Results

\begin{tabular}{|c|c|c|}
\hline $\mathrm{X} 1$ & $8,858 / 0,295$ & 9,153 \\
\hline $\mathrm{X} 2$ & $5,192 / 0,205$ & 5,397 \\
\hline $\mathrm{X} 3$ & $0,328 / 0,050$ & 0,378 \\
\hline $\mathrm{X} 4$ & $0,522 / 0,067$ & 0,590 \\
\hline $\mathrm{X} 5$ & $0,912 / 0,093$ & 1,005 \\
\hline $\mathrm{X} 6$ & $0,195 / 0,044$ & 0,238 \\
\hline $\mathrm{X} 7$ & $1,593 / 0,118$ & 1,711 \\
\hline $\mathrm{X} 8$ & $1,908 / 0,128$ & 2,036 \\
\hline
\end{tabular}

Next Calculate the value of Consistency Index (CI) and lamda. The lamda value $\lambda$ is the average value of the Consistency Vector.

$$
\begin{aligned}
\lambda & =9,153+5,397+0,378+0,590+1,05+0,238+1,711+2,036 / 8 \\
& =2,564
\end{aligned}
$$

lamda value is obtained, next step calculates the CI value.

$\mathrm{CI}=(2,564-8) /(8-1)=-5,436 / 7=\mathbf{- 0 , 7 7 6 5}$

Last count CR value (Consistency Ratio). CR value is used to see the final result of whether the search criteria and alternatives in accordance with the given provisions. If the value of CR $<0.10$, then decision making is considered consistent, but if the alternative value is greater or inconsistent then it needs to be recalculated to get a consistent value.

Table 5. Consistency Test Results.

\begin{tabular}{|c|c|c|c|c|}
\hline Criteria & $\Lambda$ maks & CI & CR & Ket \\
\hline X1 & 8,858 & 2,564 & $-0,550$ & Consisten \\
\hline X2 & 2,088 & 0,844 & $-0,938$ & Consisten \\
\hline X3 & 1,665 & 0,904 & $-1,005$ & Consisten \\
\hline X4 & 1,583 & 0,916 & $-1,018$ & Consisten \\
\hline X5 & 1,652 & 0,906 & $-1,007$ & Consisten \\
\hline X6 & 1,670 & 0,904 & $-1,004$ & Consisten \\
\hline X7 & 1,758 & 0,891 & $-0,990$ & Consisten \\
\hline X8 & 1,831 & 0,881 & $-0,979$ & Consisten \\
\hline
\end{tabular}




\section{Discussion}

Next determine the pairwise comparison matrix subcriteria. The final result can be seen in figure 4

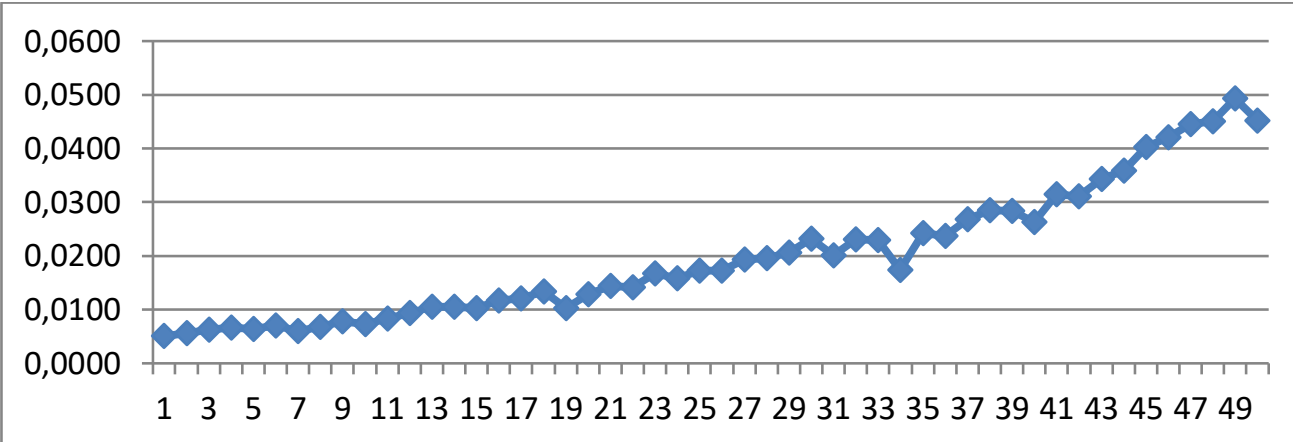

Figure 4 . Graph Resultof Matriks.

From the result matrix above, then obtained the final value for best ranking using AHP method can be seen in table 6 .

Table 6. Employee Value Results

\begin{tabular}{|l|c|r|}
\hline Goal & Mean Value & Rank \\
\hline K41 & 0,0314 & 10 \\
\hline K42 & 0,0310 & 9 \\
\hline K43 & 0,0343 & 6 \\
\hline K44 & 0,0359 & 8 \\
\hline K45 & 0,0402 & 4 \\
\hline K46 & 0,0420 & 5 \\
\hline K47 & 0,0445 & 3 \\
\hline K48 & 0,0450 & 7 \\
\hline K49 & 0,0493 & 1 \\
\hline K50 & 0,0452 & 2 \\
\hline
\end{tabular}

Using the F-AHP methodfirst stage, the criteria and the weight of the alternative importance must be compared. For that, there must be a linguistic term and an equivalent fuzzy number that shows the size of the comparison. The terms of linguistic comparison and the equivalent fuzzy numbers considered in this journal. By following the steps and calculations of the FAHP procedure, a ranking of strategies is obtained. 
Table 7. Number of Fuzzy numbers.

\begin{tabular}{|c|c|c|c|c|c|}
\hline $\mathbf{L}$ & $\mathbf{M}$ & $\mathbf{U}$ & $\sum \mathbf{L}$ & $\sum \mathbf{m}$ & $\sum \mathbf{u}$ \\
\hline 1 & 1 & 1 & 3 & 3 & 3 \\
\hline $1 / 4$ & $1 / 3$ & 1 & $3 / 12$ & $4 / 12$ & $1 / 12$ \\
\hline $1 / 3$ & $1 / 2$ & 1 & $2 / 6$ & $3 / 6$ & 1 \\
\hline 1 & 1 & 1 & 3 & 3 & 3 \\
\hline 1 & 1 & 1 & 3 & 3 & 3 \\
\hline $1 / 3$ & $1 / 2$ & 1 & $2 / 6$ & $3 / 6$ & 1 \\
\hline 1 & 1 & 1 & 1 & 1 & 1 \\
\hline $1 / 3$ & $1 / 2$ & 1 & $2 / 6$ & $3 / 6$ & 1 \\
\hline
\end{tabular}

The data used using the AHP method on the first test with the first 10 samples resulted in total $(0.0050,0.0057,0.0060,0.0067,0.0064,0.0070,0.0060,0.0067,0.0079$ and 0.0074$)$, then the second test resulted $(0.0083,0.0093,0.0105,0.0102,0.0107,0.0117,0.0121,0.0133,0.0103$ dan 0.0129$)$. there is a slight increase until finally on the fifth test it produces $(0.0315,0.0311$, $0.0344,0.359,0.0420,0.0402,0.0466,0.0451,0.0493$ and 0.0452).

Having obtained value on AHP method, then forwarded using Fuzzy AHP method. The first experiment consisted of 10 samples, the first test yielded the total $(0.250,0.457,0.363,0.467$, $0.364,0.270,0.160,0.670,0.379$ and 0.274$)$, then the second test resulted $(0.283,0.393$, $0.405,0.202,0.407,0.317,0.321,0.133,0.213$ and 0.129$)$. there is a slight increase but not stable, the test is repeated until finally on the fifth test it produces $(0.415,0.319,0.344,0.529$, $0.290,0.202,0.618,0.451,0.593$ and 0.952 ).

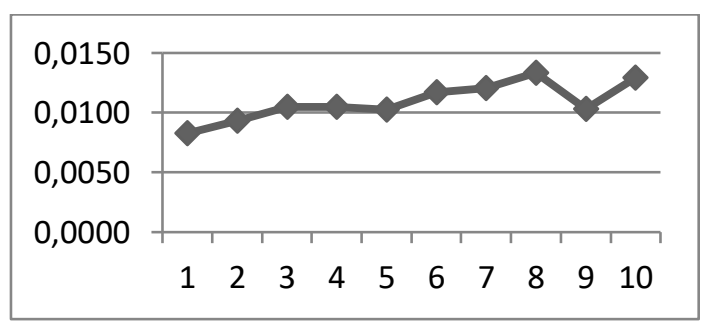

Figure 5. Image display The first Test Phase uses the AHP method

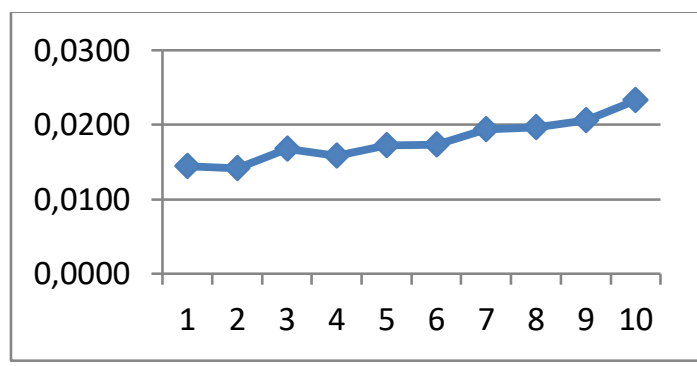

Figure 6. The image view of the Fifth Testing Stage using the AHP method 


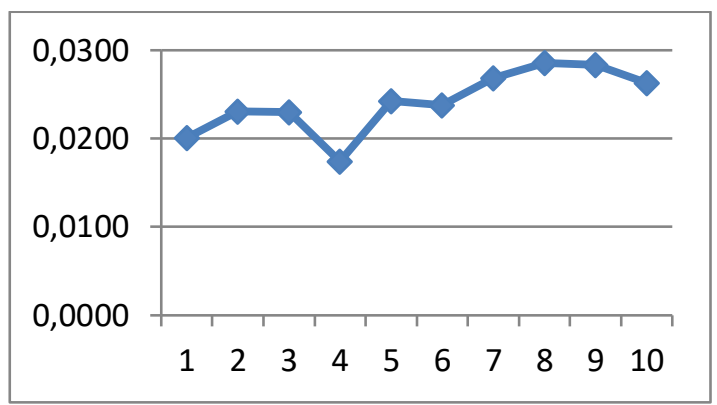

Figure 7. Graphical display First Test Phase using F-AHP

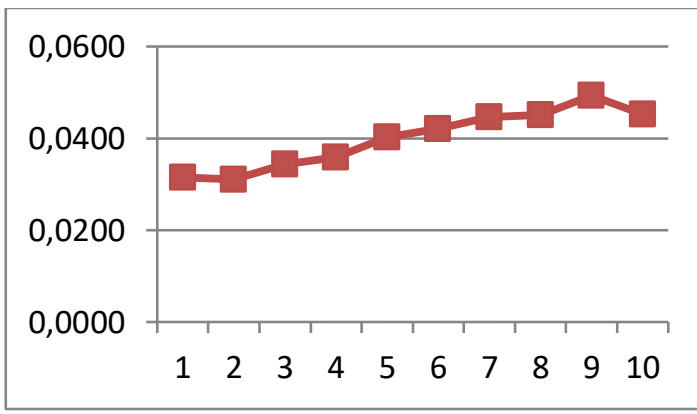

Figure 8. Graphical Views of the Fifth Testing Stage using the F-AHP method.

From the previous test results, then obtained the final value for the best ranking using F-AHP method can be seen in table 8 .

Table 8. Employee Value Accuracy Results

\begin{tabular}{|c|c|c|}
\hline Goal & Average & Rank \\
\hline K41 & 0,4142 & 10 \\
\hline K42 & 0,4105 & 9 \\
\hline K43 & 0,4434 & 6 \\
\hline K44 & 0,4595 & 8 \\
\hline K45 & 0,5027 & 4 \\
\hline K46 & 0,5206 & 5 \\
\hline K47 & 0,5453 & 3 \\
\hline K48 & 0,5507 & 7 \\
\hline K49 & 0,5949 & 1 \\
\hline K50 & 0,5529 & 2 \\
\hline
\end{tabular}


Table 8 can be seen that the highest value obtained by employee to 49 with value $(0,5933)$ compared with other employees.

\section{Conclusion}

The results of decision making accuracy analysis using Fuzzy AHP show that there is a good accuracy improvement when using Fuzzy AHP method compared using AHP. The best employee rank value generated using the AHP method is 0.0493 or $49.3 \%$. Furthermore, conducted several times testing to find accuracy using Fuzzy AHP method, it increased to 0,5949 or equal to $59,4 \%$. Thus it can be said that by using the method of Fuzzy AHP to find the accuracy of decision making to find the best employees rank can be used as a solution as an alternative.

\section{References}

[1] T. L. Saaty, "Decision making with the analytic hierarchy process," vol. 1, no. 1, 2008.

[2] M. Moayeri, A. Shahvarani, and M. H. Behzadi, "Comparison of Fuzzy AHP and Fuzzy TOPSIS Methods for Math Teachers Selection," vol. 8, no. July, 2015.

[3] I. Rijayana, L. Okirindho, F. Teknik, and U. Widyatama, "Sistem pendukung keputusan pemilihan karyawan berprestasi berdasarkan kinerja menggunakan metode analityc hierarcy process," vol. 2012, no. semnasIF, pp. 48-53, 2012.

[4] L. Dokumen, P. Ahp, A. H. Process, and T. L. Saaty, "Pengenalan Metode AHP ( Analytical Hierarchy Process )," pp. 1-11, 2010.

[5] Cabala, P. 2010. "Using The Analytic Hierarchy Process In Evaluating Decision Alternatives". Operationsresearch and decisions. No.1, 27: 31-510..

[6] Faisol, A., Aziz A.M., Suyono,H. 2014. "KomparasiFuzzy AHP dengan AHP padaSistemPendukungKeputusanInvestasiProperti”. Jurnal EECCIS, Vol.8 No,2. 123-128.

[7] KabirdanAhsan, (2011), "Comparative Analysis of AHP and Fuzzy AHP Models for Multicriteria Inventory Classification”, International Journal of Fuzzy Logic Sistems (IJFLS), 1, hal. 1-16.

[8] Moayeri, M., A. Shahvarani., M.H. Behzadi. And F. Hosseinzadeh - Lotfi, 2015. "Comparison of Fuzzy AHP and Fuzzy TopsisMetodhs for math teacher selection". Indian Journal Science and Technnology, Vol.8, 131-10,DOI: 10.17485/ijst/2015/08i13/54100, July 2015.

[9] Mohaghar, A., M.R. Fathi.,M.K. Zarchi., A. Omidian. 2012.“A Combine ViKOR - Fuzzy AHP Approach to Marketing Strategy Selection”.Business Management and Strategy. Vol.3, No.1,25:13-27.

[10] Rijayana, I. 2012. "Sistem Pendukung keputusan pemilihan karyawan berprestasi berdasarkan kinerja menggunakan metode AHP”. Jurnal Semnas IF. Vol. 1. 60:56-62.

[11] Saaty, T. L., The Analytical Hierarchy Process, New York: McGraw-Hill, 1991.

[12] Torfi, F., Farahani, R.Z., and S. Rezapour. 2010. "Fuzzy AHP to determine the relative weights of evaluation criteria and Fuzzy TOPSIS to rank the alternatives”.Applied Soft Computing 10:520528. DOI: 10.1016/j.asoc.2009.08.021. 